Article

\title{
Vegetative Propagation and ISSR-Based Genetic Identification of Genotypes of Ilex aquifolium 'Agrifoglio Commune'
}

\author{
Maria Tsaktsira ${ }^{1, *}$, Eleana Chavale ${ }^{1}$, Stefanos Kostas ${ }^{2} \mathbb{D}$, Elias Pipinis ${ }^{3}$, Parthena Tsoulpha ${ }^{1}$, \\ Stefanos Hatzilazarou ${ }^{2}$ D , Fotios-Theocharis Ziogou ${ }^{2}$, Irini Nianiou-Obeidat ${ }^{4}$, Ivan Iliev ${ }^{5}$, \\ Athanasios Economou ${ }^{2}$ and Apostolos Scaltsoyiannes ${ }^{1}$
}

1 Laboratory of Forest Genetics and Plant Breeding, School of Forestry and Natural Environment, Aristotle University, 54124 Thessaloniki, Greece; eleanace@for.auth.gr (E.C.); thena@for.auth.gr (P.T.); skaltsoy@for.auth.gr (A.S.)

2 Laboratory of Floriculture, School of Agriculture, Aristotle University, 54124 Thessaloniki, Greece; skostas@agro.auth.gr (S.K.); hatzilaz@agro.auth.gr (S.H.); fotiziog@agro.auth.gr (F.-T.Z.); aseconom@agro.auth.gr (A.E.)

3 Laboratory of Silviculture, School of Forestry and Natural Environment, Aristotle University, 54124 Thessaloniki, Greece; epipinis@for.auth.gr

4 Laboratory of Genetics and Plant Breeding, School of Agriculture, Aristotle University, 54124 Thessaloniki, Greece; nianiou@agro.auth.gr

5 Faculty of Ecology and Landscape Architecture, University of Forestry, 10 Kliment Ohridski Blvd., 1797 Sofia, Bulgaria; ivilievltu@yahoo.com

Citation: Tsaktsira, M.; Chavale, E.; Kostas, S.; Pipinis, E.; Tsoulpha, P.; Hatzilazarou, S.; Ziogou, F.-T.; Nianiou-Obeidat, I.; Iliev, I.; Economou, A.; et al. Vegetative Propagation and ISSR-Based Genetic Identification of Genotypes of Ilex aquifolium 'Agrifoglio Commune'. Sustainability 2021, 13, 10345. https:// doi.org/10.3390/su131810345

Academic Editors: Nikos Krigas and Georgios Tsoktouridis

Received: 7 August 2021

Accepted: 6 September 2021

Published: 16 September 2021

Publisher's Note: MDPI stays neutral with regard to jurisdictional claims in published maps and institutional affiliations.

Copyright: (C) 2021 by the authors Licensee MDPI, Basel, Switzerland. This article is an open access article distributed under the terms and conditions of the Creative Commons Attribution (CC BY) license (https:// creativecommons.org/licenses/by/ $4.0 /)$.
* Correspondence: tsaktsir@for.auth.gr; Tel.: +30-2310992777

Abstract: The market demand for interesting varieties and cultivars of Ilex aquifolium necessitates the exploration and sustainable exploitation of plant individuals thriving in nature without human care. In this work, an effort was made to develop a simple and reliable protocol for vegetative propagation of I. aquifolium plants, with desirable-for-market characteristics, grown in a mountain area of Halkidiki, Greece, and at the same time to proceed with their genetic identification using molecular markers. From these plants, new plants were vegetatively produced which afterward were used as stock plants for providing the needed shoot cuttings for the experiments of rooting and leaves for their genetic analysis. Factors studied in formulating a propagation protocol included the season of cutting collection and the application of $0.2 \%$ 1-naphthaleneacetic acid (NAA), as well as the type of shoot cuttings (terminal, subterminal) and the application of auxin. It was found that application of NAA was crucial for rooting response and number of roots formed, whereas the season effect was not significant on rooting. Terminal cuttings treated with $0.2 \%$ NAA exhibited the highest rooting percentage (100\%) and formed abundant roots (25.7) compared to subterminal ones. All rooted cuttings, after being potted and transferred to acclimatization greenhouse, were successfully hardened. In the spring of the next year, the produced plants blossomed abundantly and formed fruits (bright red berries) presenting their characteristic ornamental appearance that was maintained until Christmas. For the identification procedure, the genotypic profile of the stock plants was also investigated by inter-simple sequence repeat (ISSR) genetic analysis, revealing that they were genetically the same both among themselves and when compared with a certified I. aquifolium 'Agrifoglio Commune' individual, but they differed genetically from I. aquifolium 'Argentea Marginata' and I. aquifolium 'Hellas'.

Keywords: biodiversity; English holly; molecular markers; NAA; ornamentals; PCoA; propagation protocol; shoot cuttings; STRUCTURE

\section{Introduction}

Ilex aquifolium (English holly), found in many mountain areas of Greece, includes numerous genotypes known for their ornamental value due to the diversity of foliage (shape, form, color), fruit morphology and color, plant canopy and other characteristics [1-3]. It is a 
dioecious plant species $(2 n=40)$ with female and male flowers on different plants. Female plants bear decorative red fruits which remain on the plant throughout the winter [1]. Plant material of I. aquifolium from mountain areas is an excellent source for exploitation through ex situ conservation and sustainable production by vegetative propagation to meet the demands of the ornamental market.

I. aquifolium 'Agrifoglio Commune' is a commercial cultivar used in gardens, parks and generally in landscapes planted single, in groups or in hedges. It is an evergreen shrub or small tree with shiny deep green leaves with margins not quite as spiny as typical hollies. Small fragrant white flowers bloom in spring. The female plants are highly valued in the market for the characteristic profound bright red berries maturing in autumn, which still decorate the plant in Christmas time and beyond.

It has been demonstrated that the limiting factors for the vegetative propagation of woody species are the age, the physiological status of the mother plants (e.g., the season of cutting collection), the genotype peculiarity of the donor plant and the environmental conditions during rooting $[4,5]$. Propagation by shoot cuttings, which ensures retention of the good traits of the mother plant to the offspring, is the main technique used for reproduction of I. aquifolium [4-7]. Previous research by Tsaktsira et al. [8] indicated that among I. aquifolium cultivars and varieties, 'Agrifoglio Commune' outperformed in rooting experiments. Literature on detailed propagation protocols of specific holly cultivars is limited to hollies such as Ilex glabra 'Nigra' [9], Ilex vomitoria 'Nana' [9,10], Ilex vomitoria 'Dare County' [11], Ilex cornuta 'Dwarf Burford' [12], Ilex crenata 'Heller' [13] and Ilex x meserveae 'Blue Girl' [14], but scarcely for I. aquifolium varieties [8].

Genetic analysis using molecular markers is a useful tool to determine the relationship between genotypes or populations, with greater accuracy compared to the phenotypicmorphological taxonomic characterizations of the past. Molecular markers ISSRs are considered suitable for detailed taxonomy in relative species and are applied on plants of the same species to determine the genetic distance between genotypes [15]. Moreover, they are ideal for species with limited genetic information, as in the case of I. aquifolium, as no special primers need to be constructed [16,17]. In addition, ISSRs are simple, easy to handle, widely available, reliable and highly effective [18-22].

In nursery practice and especially in ornamental plant trade in the market, the authenticity of cultivars of I. aquifolium is a widespread problem [23]. Moreover, according to Graf [23], unavailable cultivars of I. aquifolium of high demand were replaced by similar cultivars devoid of any certification of authenticity, while existing taxonomic keys are based on only a small number of cultivars or comprise too many unknown cultivars. Nowadays, the ornamental market needs a continuous and sustainable supply of authentic plants produced by a standard and reliable propagation procedure.

This work aims at developing a functional, simple and practical protocol of vegetative propagation from certified stock plant material examined by ISSR markers, readily applicable on I. aquifolium varieties and cultivars. The streamlining of the propagation of I. aquifolium varieties and cultivars will ensure commercial success for the mass-scale production of genetically and morphologically homogeneous plants in the nursery units.

\section{Materials and Methods}

\subsection{Plant Material and Rooting Procedure}

The material used for the experiments originated from I. aquifolium female plants grown in an experimental area of the Laboratory of Forest Genetics and Plant Breeding, at Polygyros, Halkidiki, Greece (latitude $40^{\circ} 22^{\prime} 32.2^{\prime \prime} \mathrm{N}$, longitude $23^{\circ} 28^{\prime} 35.5^{\prime \prime} \mathrm{E}$, altitude $560 \mathrm{~m}$ ). These female plants had morphological characteristics resembling those of the trade cultivar I. aquifolium 'Agrifoglio Commune'; thus, for possible exploitation purposes, a number of new plants were produced through vegetative propagation and established in the greenhouse at the premises of the Laboratory of Forest Genetics and Plant Breeding, Thessaloniki, Greece (latitude 40 $33^{\prime} 59.7^{\prime \prime} \mathrm{N}$, longitude $22^{\circ} 58^{\prime} 13.5^{\prime \prime}$ E, altitude $10 \mathrm{~m}$ ). Fifteen plants, aged three years, were randomly selected and used as stock plants for providing 
material for the experiments of propagation and genetic analysis. The excised shoots (30-40 cm long) from these stock plants were placed in plastic bags wrapped in moistened filter paper and cold-stored at $3-5{ }^{\circ} \mathrm{C}$ for 10 days prior to their use. After cold storage, from the collected shoots, two types of cuttings related to their position on the shoot were produced, the terminal cuttings (apical portion of shoot) and the subterminal cuttings (basal portion of shoot), which then were trimmed to a final length of $15 \mathrm{~cm}$, while leaves were removed from their basal part. The bases $(1 \mathrm{~cm})$ of the cuttings were dipped for $10 \mathrm{~s}$ into a $50 \%$ ethanol solution for surface disinfestation and then in a talc powder (Rhizopon B) containing $0.2 \%(w / w)$ NAA (Rhizopon BV, Rijndijk, the Netherlands). Subsequently, the cuttings were lightly shaken to remove excess powder and then, together with the non-NAA-treated cuttings that were dipped only into $50 \%$ ethanol solution (control), were planted in 40-cell plastic trays (cell dimensions $6 \times 6 \times 12 \mathrm{~cm}$ ) filled with perlite (Isocon, Athens, Greece) as a rooting substrate. The plastic trays with the planted cuttings were randomly placed for rooting on the bench under an intermittent mist system (Figure 1A). Rooting results were determined 10 weeks later.

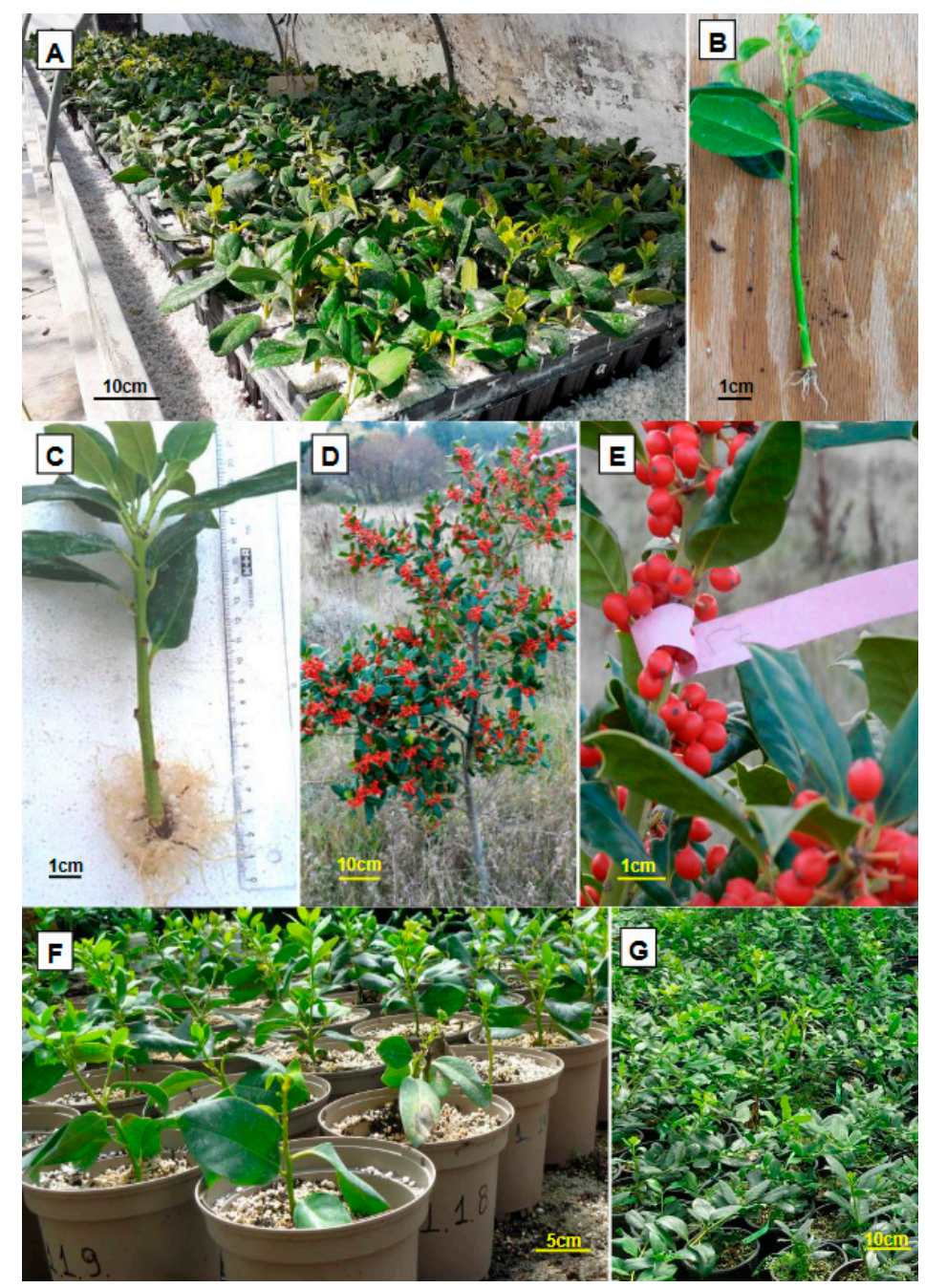

Figure 1. (A) Shoot cuttings of I. aquifolium on mist rooting system. (B) Rooted cutting without NAA treatment. (C) Rooted cutting after treatment with $0.2 \%$ NAA. (D) Certified I. aquifolium 'Agrifoglio Commune' plant used for ISSR genetic analysis. (E) Close-up photo of certified I. aquifolium 'Agrifoglio Commune' branch with red berries. (F) Plantlets, 4 weeks after transplanting of rooted cuttings. (G) I. aquifolium 'Agrifoglio Commune' plants of (F), one year later, exhibited successful growth and development. 
The temperature at the bottom of the bench of the intermittent mist, in proximity to the basal end of the planted cuttings, was maintained at $20 \pm 1^{\circ} \mathrm{C}$, with the aid of electrical cables, while the water mist was applied periodically (five or ten times of one minute each on a daily basis, in autumn or spring cutting collection, respectively). Apart from the natural daylight, during the rooting period of autumn to winter, a $16 \mathrm{~h}$ photoperiod was provided to cuttings by supplementary lighting furnished by $400 \mathrm{~W}$ halogen lamps of photosynthetic photon flux density (PPFD) of $115 \mu \mathrm{mol} \cdot \mathrm{m}^{-2} \cdot \mathrm{s}^{-1}$ measured at cutting level. The ambient temperature at the greenhouse was $23 \pm 1{ }^{\circ} \mathrm{C}$ in autumn to winter and $26 \pm 1^{\circ} \mathrm{C}$, using a cooling system, in spring to summer rooting of cuttings.

\subsection{Effect of Season and Auxin Treatment on Rooting of Cuttings}

To study the effect of physiological condition of the donor plant on the rooting of terminal cuttings, they were collected in spring (early April) and autumn (middle November) from the three-year-old stock plants and were tested for their rooting ability in the intermittent mist system as described previously. Half of the cuttings received treatment with $0.2 \%$ NAA (Rhizopon B), while the other half did not (control). Each season and auxin treatment included four replications of 20 cuttings each. After rooting evaluation (Figure 1B,C), all rooted cuttings were transplanted to $2 \mathrm{~L}$ pots, filled with a mixture of 3:1 $(v / v)$ peat TS2 Klasmann (Klasmann-Deilmann, Geeste, Germany) and perlite, which afterward were transferred to the acclimatization greenhouse for hardening.

\subsection{Effect of Type of Cutting and Auxin Treatment on Rooting of Cuttings}

To study the effect of position of the cutting on the shoots collected in autumn (November), after being cold-treated as described previously, terminal (apical portion) and subterminal (remaining basal portion) cuttings were excised and used for rooting. Half of both types of cuttings were auxin-treated (0.2\% NAA) and together with the untreated ones (control) were placed for rooting on the intermittent mist bench as described previously. Each type of cutting and auxin treatment contained four replications of 20 cuttings each. After rooting evaluation, rooted cuttings were transplanted in 2 L pots containing a mixture of 3:1 $(v / v)$ peat TS2 Klasmann and perlite, which afterward were transferred to the acclimatization greenhouse for hardening.

\subsection{Data Recording and Statistical Analysis}

In each experiment, the rooting response of the cuttings was assessed after a period of 10 weeks from establishment in the rooting substrate. At the same time, the number and the length of roots of each rooted cutting were recorded. A cutting was considered as rooted when at least one root $\geq 0.5 \mathrm{~cm}$ was formed.

In both experiments, a completely randomized design was applied. Data in percentages were subjected to arcsine transformation for proportions before analysis and converted back to percentages for presentation in tables. The effect of treatments and their interactions for each experiment were analyzed using the ANOVA method in the frame of the general linear model (GLM), while the comparisons between the means were made using the Bonferroni test at the significance level of $p \leq 0.05$ [24]. All statistical analyses were carried out using SPSS v.21 software (SPSS, Inc., Statistical Package for the Social Sciences, Chicago, IL, USA).

\subsection{Genomic DNA Isolation}

For the genetic assessment, shoots were selected from the 15 stock plants, dried for one week and stored in the herbarium of the Laboratory of Floriculture, Thessaloniki, Greece, with the code numbers IAAC101-IAAC115. The same procedure was followed for three other I. aquifolium plants for comparisons. One of these was a certified plant of I. aquifolium 'Agrifoglio Commune' (IA) (grown in Polygyros, Halkidiki, Greece) (Figure 1D,E), and the other two were plants of the a priori known I. aquifolium cv. Argentea Marginata (D) and I. aquifolium var. Hellas. Genomic DNA (gDNA) was extracted from leaves of 
these 18 plants applying the cetyl-trimethyl ammonium bromide (CTAB) method. Leaf tissue $(100 \mathrm{mg}$ ) was ground into fine powder by using liquid nitrogen and homogenized in $800 \mu \mathrm{L}$ CTAB buffer (0.1 M Tris- $\mathrm{HCl}, 1.4 \mathrm{M} \mathrm{NaCl}, 0.02 \mathrm{M}$ EDTA, $2 \%$ CTAB and $0.2 \%$ $\beta$-mercaptoethanol). Then, $2 \mu \mathrm{L}$ RNase $(10 \mathrm{mg} / \mathrm{mL})$ was added and mixed thoroughly by vortexing. The homogenate was transferred to a $65{ }^{\circ} \mathrm{C}$ bath for $45 \mathrm{~min}$ (vortexing every $15 \mathrm{~min}$ ) and was centrifuged for $10 \mathrm{~min}$ at $16,000 \mathrm{rpm}$. The supernatant was transferred to a new tube, and $800 \mu \mathrm{L}$ chloroform was added. After vortexing, the sample was centrifuged at $7000 \mathrm{rpm}$ for $20 \mathrm{~min}$ to separate the phases. The aqueous upper phase was transferred, again, to a new tube. The extraction with $800 \mu \mathrm{L}$ chloroform was repeated once more, and the final clear upper phase was transferred into a new tube. DNA was precipitated by adding 0.7 volume of isopropanol and 0.1 volume of sodium acetate $(3 \mathrm{M})$ and incubated at $-20{ }^{\circ} \mathrm{C}$ overnight. After incubation, the sample was centrifuged at $16,000 \mathrm{rpm}$ for $10 \mathrm{~min}$. The supernatant was decanted without disturbing the pellet and subsequently washed twice with $1 \mathrm{~mL}$ of $70 \%$ ethanol. Ethanol was added, without mixing, followed by centrifugation at 16,000 rpm for $10 \mathrm{~min}$. The supernatant was removed without disturbing the pellet, and the sample was air-dried for $5 \mathrm{~min}$. DNA was dissolved in a $37^{\circ} \mathrm{C}$ bath for $1 \mathrm{~h}$ with $100 \mu \mathrm{L} 1 \mathrm{X}$ TE buffer (Tris-EDTA) and $2 \mu \mathrm{L}$ RNase $(10 \mathrm{mg} / \mathrm{mL})$ and stored at $-20{ }^{\circ} \mathrm{C}$.

The quality of the extracted DNA was assessed using $0.8 \%$ agarose gel electrophoresis, by mixing with loading buffer in a ratio of $1: 5$, and compared with $\lambda$-Hind III ladder (H3) (Figure 2). The concentration A260/A280 and A260/A230 ratios were measured with a NanoDrop 2000c Spectrophotometer (Thermo Electron Corporation, Waltham, MA, USA) using $1 \mu \mathrm{L}$ of each sample and with 1X TE buffer (Tris-EDTA) as blank. Analysis of the A260/A280 values of the samples showed all ratios being within the acceptable range of $1.80-2.10$.

H3

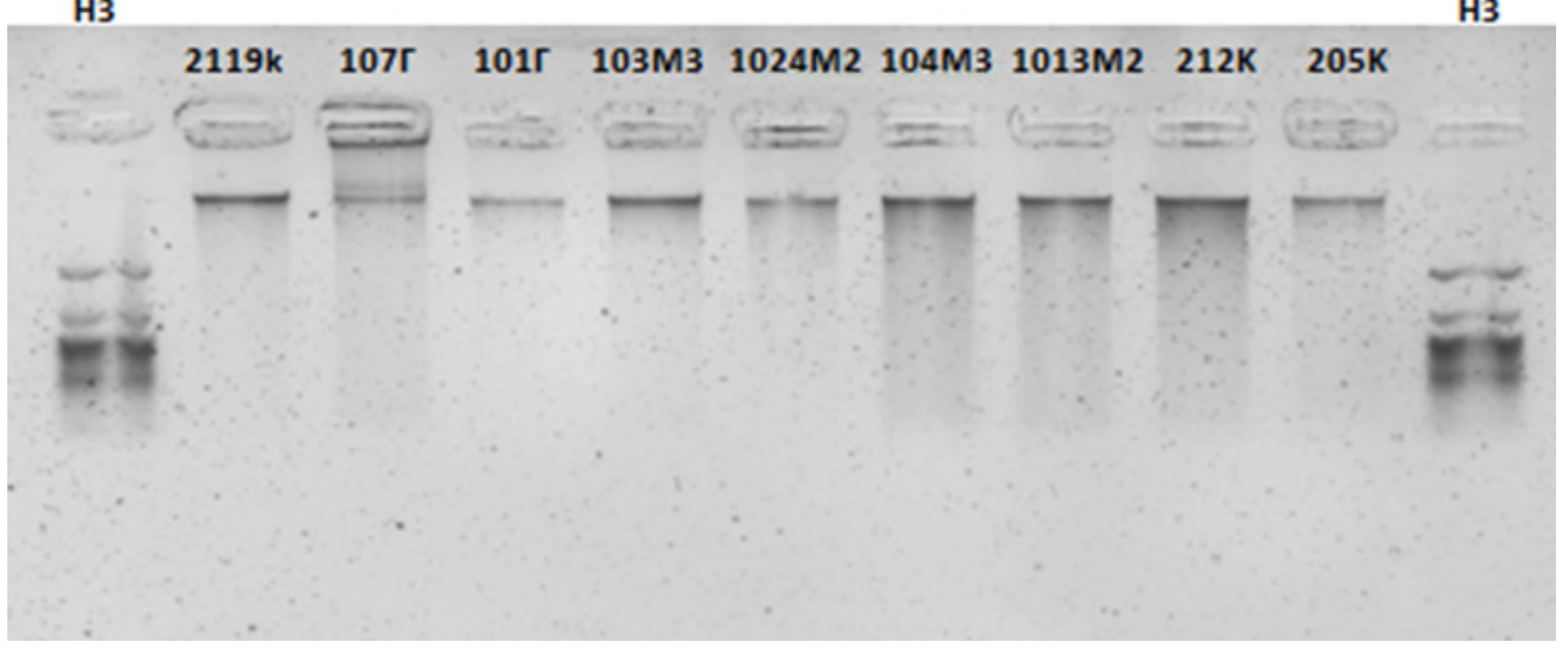

Figure 2. Agarose gel electrophoresis of nine I. aquifolium gDNA samples compared with $\lambda$-Hind III ladder (H3).

\subsection{PCR Amplification}

For PCR amplifications of the eight ISSR primers tested (Table 1), a SimpliAmp Thermal Cycler (Life Technologies, Thermo Fischer Scientific, Waltham, MA, USA) was used. The initial single denaturation step at $95^{\circ} \mathrm{C}$ for 3 min was followed by 35 cycles of denaturing at $95{ }^{\circ} \mathrm{C}$ for $30 \mathrm{~s}$, annealing of primers at $50-56{ }^{\circ} \mathrm{C}\left(\mathrm{Tm}{ }^{\circ} \mathrm{C}\right.$, Table 1$)$ for $30 \mathrm{~s}$ and extension at $72{ }^{\circ} \mathrm{C}$ for $2 \mathrm{~min}$. The reaction was completed with a final extension step at $72{ }^{\circ} \mathrm{C}$ for $10 \mathrm{~min}$, followed by adjusting at $4{ }^{\circ} \mathrm{C}$. A total volume of $15 \mu \mathrm{L}$ was used, containing $7.5 \mu \mathrm{L}$ Horse-Power Taq DNA Polymerase Master-Mix (Canvax Biotech, Cordoba, Spain),

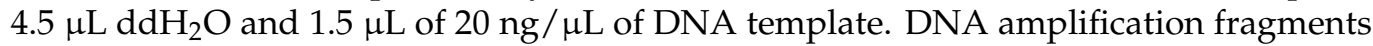


were separated in a $1.4 \%$ agarose gel with $1 \mathrm{X}$ Tris-acetate electrophoresis buffer (1X TAE), stained with ethidium bromide $(0.5 \mu \mathrm{g} / \mathrm{mL})$ and analyzed using UV light (UST-20M$8 \mathrm{~K}, 312 \mathrm{~nm}$ ) (Biostep, Burkhardsdorf, Germany). The size of the amplification products was calculated based on molecular mass 100-3000 bp DNA Rainbow ladder (Canvax Biotech, Cordoba, Spain). Two independent PCR amplification reactions were performed for each sample.

Table 1. Profiles of the eight selected ISSR primers (annealing temperature, amplified and polymorphic bands and polymorphism per primer) used for the genetic assessment of the 18 I. aquifolium plants.

\begin{tabular}{|c|c|c|c|c|c|c|}
\hline & Primer & $\begin{array}{l}\text { Sequence } \\
\left(5^{\prime}-3^{\prime}\right)\end{array}$ & $\begin{array}{l}\mathrm{Tm} \\
\left({ }^{\circ} \mathrm{C}\right)\end{array}$ & $\begin{array}{c}\text { Number of } \\
\text { Amplified } \\
\text { Bands }\end{array}$ & $\begin{array}{c}\text { Number of } \\
\text { Polymorphic } \\
\text { Bands }\end{array}$ & $\begin{array}{l}\text { Polymorphism } \\
(\%)\end{array}$ \\
\hline 1 & UBC-809 & AGA GAG AGA GAG AGA GG & 54 & 14 & 13 & 92.86 \\
\hline 2 & UBC-810 & GAG AGA GAG AGA GAG AT & 52 & 9 & 8 & 88.89 \\
\hline 3 & UBC-815 & СТС ТСТ СТС ТСТ СТС ТG & 50 & 13 & 10 & 76.92 \\
\hline 4 & UBC-816 & CAC ACA CAC ACA CAC AT & 54 & 12 & 10 & 83.33 \\
\hline 5 & UBC-818 & CAC ACA CAC ACA CAC AG & 56 & 13 & 11 & 84.62 \\
\hline 6 & UBC-834 & AGA GAG AGA GAG AGA GYT & 56 & 8 & 5 & 62.50 \\
\hline 7 & UBC-841 & GAG AGA GAG AGA GAG AYC & 54 & 11 & 10 & 90.91 \\
\hline 8 & UBC-845 & СТС TCT СТС TCT СТС TRG & 50 & 7 & 1 & 14.29 \\
\hline
\end{tabular}

Related analyses to estimate genetic relationship were conducted according to Nei genetic distance [25] and used for the construction of:

I. The principal coordinates analysis (PCoA) with GenAlEx 6.501 program [26]. The PCoA input data type was tri distance matrix, and the PCoA method was covariancestandardized.

II. A STRUCTURE analysis, where similarity estimates were analyzed using the Structure 2.3.4 software package [27]. This software places cultivars in $K$ clusters that have distinct marker frequencies, where $K$ is chosen a priori and can be varied across different runs $(K=1-8)$. Samples can have memberships in several clusters, with membership coefficients equaling 1 across clusters. A nonadmixture ancestry model was used and binary frequencies were correlated, with a burn-in length of 30,000 followed by 100,000 runs at each $K[28,29]$. $K$ was determined using the ad hoc statistic $\Delta K$ as in Evanno et al. [30] with STRUCTURE HARVESTER program [31].

III. An unweighted paired group method of cluster analysis (UPGMA) dendrogram with MEGA 4 v.4.1 software [32].

\section{Results and Discussion}

\subsection{Effect of Season and Auxin Treatment on Rooting of Cuttings}

Season (spring, autumn) was not a significant factor influencing the rooting of Ilex terminal cuttings $(\mathrm{F}=0.673 ; p>0.05)$. On the contrary, auxin treatment $(0.2 \% \mathrm{NAA})$ significantly influenced rooting response, followed by the interaction of season and auxin treatment $(\mathrm{F}=215.606$ and 12.587 , respectively; $p \leq 0.05)$ (Table 2$)$. Similarly, the number of roots was affected only by auxin treatment (Figure 1B,C) and by the interaction between the factors of season and auxin ( $\mathrm{F}=156.775$ and 16.869 , respectively; $p \leq 0.05)$ (Table 2$)$. Furthermore, the analyses of variance indicated that the length of roots was significantly influenced by season $(\mathrm{F}=19.870, p \leq 0.05)$, auxin treatment $(\mathrm{F}=41.295, p \leq 0.05)$ and their interaction $(\mathrm{F}=12.535, p \leq 0.05)$ (Table 2$)$. 
Table 2. Significance of factors (season, auxin) and their interaction on rooting response (\%) and number and length of roots of terminal cuttings of I. aquifolium estimated by one-way ANOVA.

\begin{tabular}{ccccccccccc}
\hline & & \multicolumn{3}{c}{ Rooting (\%) } & & & \multicolumn{2}{c}{$\begin{array}{c}\text { Number } \\
\text { of Roots }\end{array}$} & & \multicolumn{3}{c}{$\begin{array}{c}\text { Length } \\
\text { of Roots }\end{array}$} \\
\hline Factors & df & F & Sign. & df & F & Sign. & df & F & Sign. \\
\hline Season & 1 & 0.673 & NS & 1 & 0.116 & NS & 1 & 19.870 & $* * *$ \\
Auxin & 1 & 215.606 & $* * *$ & 1 & 156.775 & $* * *$ & 1 & 41.295 & $* * *$ \\
Season x Auxin & 1 & 12.587 & $* *$ & 1 & 16.869 & $* * *$ & 1 & 12.535 & $* *$ \\
\hline
\end{tabular}

Rooting percentage: $\mathrm{R}$ squared $=0.950$ (adjusted $\mathrm{R}$ squared $=0.938), p \leq 0.05$. Number of roots: $\mathrm{R}$ squared $=0.496$ (adjusted $\mathrm{R}$ squared $=$ 0.488 ), $p \leq 0.05$. Length of roots: $\mathrm{R}$ squared $=0.193$ (adjusted $\mathrm{R}$ squared $=0.180$ ), $p \leq 0.05$. ${ }^{* * *}=$ significant at $p \leq 0.0011^{* *}=$ significant at $p \leq 0.01, \mathrm{NS}=$ not significant.

In both collection times, the highest rooting percentage was observed in cuttings treated with $0.2 \%$ NAA, which reached $100 \%$ in cuttings collected in autumn (Table 3 ). However, in NAA-treated cuttings, no significant difference was observed in rooting percentages between season collections $(93.7 \%$ vs. $100 \%)$, whereas in control, cuttings collected in spring rooted in a significantly higher percentage (37.5\%) compared to those collected in autumn (13.7\%) (Table 3). The number of roots was significantly reduced in the absence of auxin in both seasons tested (Table 3, Figure 1B). Within NAA treatment, rooted cuttings collected in autumn exhibited a significantly higher number of roots (25.7) compared to those collected in spring (20.3). In contrast, without the application of NAA, the highest number of roots was observed in cuttings collected in spring (Table 3 ). The length of roots formed with the application of NAA $(3.4-3.8 \mathrm{~cm})$, regardless of collection season, was significantly greater than that of the untreated (control) cuttings of autumn collection $(1.2 \mathrm{~cm})$ but that of the spring collection cuttings $(3.0 \mathrm{~cm})($ Table 3$)$.

Table 3. Effect of season and auxin treatment on rooting response (\%) and number and length of roots of terminal cuttings of I. aquifolium.

\begin{tabular}{ccccccc}
\hline \multirow{2}{*}{ Season } & \multicolumn{2}{c}{ Rooting (\%) } & \multicolumn{2}{c}{ Number of Roots } & \multicolumn{2}{c}{ Length of Roots (cm) } \\
\cline { 2 - 7 } & Control & $\mathbf{0 . 2} \%$ NAA & Control & $\mathbf{0 . 2} \%$ NAA & Control & $\mathbf{0 . 2} \%$ NAA \\
\hline Spring & $37.5 \pm 10.4 \mathrm{~B}^{1} \mathrm{a}^{2}$ & $93.7 \pm 6.3 \mathrm{~A} \mathrm{a}$ & $8.4 \pm 5.1 \mathrm{~B} \mathrm{a}$ & $20.3 \pm 2.2 \mathrm{~A} \mathrm{~b}$ & $3.0 \pm 1.1 \mathrm{~A} \mathrm{a}$ & $3.8 \pm 1.2 \mathrm{~A} \mathrm{a}$ \\
Autumn & $13.7 \pm 7.5 \mathrm{~B} \mathrm{~b}$ & $100 \pm 0.0 \mathrm{~A} \mathrm{a}$ & $2.1 \pm 1.2 \mathrm{~B} \mathrm{~b}$ & $25.7 \pm 2.9 \mathrm{~A} \mathrm{a}$ & $1.2 \pm 0.6 \mathrm{~B} \mathrm{~b}$ & $3.4 \pm 0.9 \mathrm{~A} \mathrm{a}$ \\
\hline
\end{tabular}

1,2 The means \pm SD of rooting percentages and number and length of roots within a column followed by the same lowercase letter and within a row by the same capital letter were not significantly different, estimated by one-way ANOVA followed by a post hoc Bonferroni test at $p \leq 0.05$.

Similarly, no season effect was observed in a previous report of Tsaktsira et al. [8] on rooting of I. aquifolium 'Agrifoglio Commune' cuttings tested with the same auxin and concentration and same seasons of cutting collection. In the same report [8], however, autumn was found to be the most favorable season for rooting of cuttings of other I. aquifolium cultivars such as 'Argentea Marginata', 'J.C. van Tol' and variety 'Hellas'. The effect of season on the rooting ability of cuttings was pointed out in numerous other studies on holly vegetative propagation. Summer or early autumn harvested cutting material performed better than spring collections in terms of rooting percentage and number and length of roots, as was reported by Hartman et al. [4] for Ilex spp., Lambert et al. [11] for I. vomitoria 'Dare County' and Vlad et al. [33] for I. aquifolium.

\subsection{Effect of Type of Cutting and Auxin Treatment on Rooting of Cuttings}

The analyses of variance of cuttings collected in autumn indicated that there were significant differences in rooting response affected by the type of cutting (cutting position) $(\mathrm{F}=29.471, p \leq 0.05)$, auxin $(\mathrm{F}=639.500, p \leq 0.05)$ and the interaction between the type of cutting and auxin $(\mathrm{F}=25.130, p \leq 0.05)$, whereas the number and the length of roots were significantly affected only by auxin (Table 4 ). 
Table 4. Significance of factors (type of cutting, auxin) and their interaction on rooting response (\%) and number and length of roots of autumn cuttings of I. aquifolium estimated by one-way ANOVA.

\begin{tabular}{cccccccccc}
\hline & \multicolumn{3}{c}{ Rooting (\%) } & \multicolumn{3}{c}{ Number of Roots } & \multicolumn{3}{c}{ Length of Roots (cm) } \\
\hline Factors & df & F & Sign. & df & F & Sign. & df & F & Sign. \\
\hline Type of cutting & 1 & 29.471 & $* * *$ & 1 & 1.451 & NS & 1 & 0.516 & NS \\
Auxin & 1 & 639.500 & $* * *$ & 1 & 115.781 & $* * *$ & 1 & 104.982 & $* * *$ \\
Type of cutting x Auxin & 1 & 25.130 & $* * *$ & 1 & 0.747 & NS & 1 & 0.002 & NS \\
\hline
\end{tabular}

Rooting percentage: $\mathrm{R}$ squared $=0.983$ (adjusted $\mathrm{R}$ squared $=0.979$ ), $p \leq 0.05$. Number of roots: $\mathrm{R}$ squared $=0.435$ (adjusted $\mathrm{R}$ squared $=$ $0.425), p \leq 0.05$. Length of roots: $\mathrm{R}$ squared $=0.393$ (adjusted $\mathrm{R}$ squared $=0.382), p \leq 0.05 .{ }^{* * *}=$ significant at $p \leq 0.001$, NS $=$ not significant.

Regardless of type of cutting (terminal, subterminal), the application of NAA resulted in achieving higher rooting percentages and producing more and longer roots as compared with the control (Table 5, Figure 1B,C). However, the terminal cuttings treated with auxin exhibited higher rooting percentage and formed more roots than subterminal cuttings treated with auxin (Table 5). In general, results showed that subterminal cuttings also proved to be a good source of propagating material as rooting ability and formation of roots reached quite satisfactory levels. In both experiments, callus was not observed at the root forming area.

Table 5. Effect of type of cutting and auxin treatment on rooting response (\%) and number and length of roots of I. aquifolium cuttings collected in autumn.

\begin{tabular}{ccccccc}
\hline \multirow{2}{*}{$\begin{array}{c}\text { Type of } \\
\text { Cutting }\end{array}$} & \multicolumn{2}{c}{ Rooting (\%) } & \multicolumn{2}{c}{ Number of Roots } & \multicolumn{2}{c}{ Length of Roots (cm) } \\
\cline { 2 - 7 } & Control & $\mathbf{0 . 2} \%$ NAA & Control & $\mathbf{0 . 2} \%$ NAA & Control & $\mathbf{0 . 2} \%$ NAA \\
\hline Terminal & $13.7 \pm 7.5 \mathrm{~B}^{1} \mathrm{~b}^{2}$ & $100 \pm 0.0 \mathrm{~A} \mathrm{a}$ & $2.1 \pm 1.2 \mathrm{~B} \mathrm{a}$ & $25.7 \pm 2.9 \mathrm{~A} \mathrm{a}$ & $1.2 \pm 0.6 \mathrm{~B} \mathrm{a}$ & $3.4 \pm 0.9 \mathrm{~A} \mathrm{a}$ \\
Subterminal & $12.5 \pm 6.4 \mathrm{~B} \mathrm{~b}$ & $83.7 \pm 2.5 \mathrm{~A} \mathrm{~b}$ & $1.4 \pm 0.7 \mathrm{~B} \mathrm{a}$ & $21.5 \pm 1.2 \mathrm{~A} \mathrm{~b}$ & $1.3 \pm 0.8 \mathrm{~B} \mathrm{a}$ & $3.6 \pm 1.0 \mathrm{~A} \mathrm{a}$ \\
\hline
\end{tabular}

1,2 The means \pm SD of rooting percentages and number and length of roots within a column followed by the same lowercase letter and within a row by the same capital letter were not significantly different, estimated by one-way ANOVA followed by a post hoc Bonferroni test at $p \leq 0.05$.

To the best of our knowledge, no previous investigation on the effect of cutting position (type of cutting) on rooting of I. aquifolium was found in the literature to compare with our results. However, it is a widely studied factor for various other species contributing to the establishment of successful propagation protocols by cuttings. Mbangcolo et al. [34] reported higher rooting performance of terminal cuttings over subterminal cuttings in Cyclopia genistoides. The same authors [34] stated that, in general, the rooting responses of terminal cuttings are higher than those of the subterminal cuttings; thus, they recommended them as the best rooting material. Subterminal cuttings also possess a good potential for successful propagation of various species, as suggested by several researchers [34,35]. In Acer truncatum, Brock and Griffin [36] did not find a significant influence of cutting position for all rooting parameters tested in the presence of auxin. Furthermore, Tilahun et al. [37], working on Araucaria heterophylla, reported that among three cutting positions on the shoot (tip, middle and bottom), the shoot tip material showed significantly higher rooting ability than middle and bottom parts. Terminal shoot cuttings have proved to be the most suitable propagating material in the case of cassava (Manihot esculenta) [38] and Alstonia scholaris [39]. Solikin [40] attributed the enhanced rooting ability of terminal cuttings to their higher content in endogenous auxin concentrated at the apical part of the shoot. On the other hand, various rooting responses due to cutting position were reported for species such as Aloysia triphylla (lemon verbena) [41], Stevia rebaudiana [42], Lavandula angustifolia [43] and Salvia officinalis [44]. Hartmann et al. [4] also pointed out the effect of cutting position on rooting, stating that there is a species-dependent relation between them due to different origins of cuttings.

In general, the hardening of young I. aquifolium plantlets, which derived from rooted cuttings of both types and season collections, was successful in the acclimatization green- 
house (Figure 1F,G). Specifically, plants originating from autumn cuttings surprisingly exhibited a vigorous growth after acclimatization, followed by the formation of abundant small white blossoms that after many bee visits were transformed to green fruits in June. Fruits turned gradually to bright red in autumn and were maintained on the plants until Christmas. A sufficient number of mature seeds (four replications of 100 seeds each) were examined, and approximately only $10 \%$ of them were completely developed (data not shown). The majority of the seeds (approximately 90\%), however, were deprived of an embryo, which points to the expression of parthenocarpy and specifically the stimulative type according to Hartmann et al. [4], as the production of fruits occurred due to pollination (probably by bees) without fertilization.

\subsection{Genetic Analysis}

The PCR amplification using ISSR primers resulted in generation of 87 clear, scorable and reproducible products (bands), ranging from $150 \mathrm{bp}$ for UBC-841 to $1550 \mathrm{bp}$ for UBC845. The number of bands produced by each primer for the used samples of the 15 stock plants of I. aquifolium varied: 14 for UBC-809 (Figure 3A), 13 for UBC-815 (Figure 3B) and UBC-818, 8 for UBC-834 (Figure 3C) and 7 for UBC-845 (Table 1). The PCR-amplified products were scored as " 1 " and " 0 ", where " 1 " indicates the presence of a band and " 0 " indicates the absence. These binary data were used to detect the relationship among the 15 stock plants of I. aquifolium and the 3 indicator plants, i.e., I. aquifolium 'Agrifoglio Commune', I. aquifolium 'Argentea Marginata' and I. aquifolium 'Hellas'. The polymorphism of ISSR primers ranged from $14.29 \%$ for UBC-845 to $92.86 \%$ for UBC-809, with an average polymorphism of $74.29 \%$ (Table 1). The PCoA-ISSR data showed that $89.09 \%$ of the variation is explained by the coordinates 1,2 and 3 , with the first coordinates explaining $60.82 \%$, the second ones $26.10 \%$ and the third ones $2.17 \%$ of total variation (Figure 4 , Table S1). The 15 samples each of the 15 stock plants of I. aquifolium and that of the certified plant of I. aquifolium 'Agrifoglio Commune' (IA) were segregated in the PCoA from the samples of the two other indicator plants, i.e., I. aquifolium 'Argentea Marginata' (D) and I. aquifolium 'Hellas' (H). The 15 samples of the stock plants and the one sample of the certified 'Agrifoglio Commune' plant were concentrated at the same point on the left part of the PCoA, whereas the plant samples of 'Hellas' and 'Argentea Marginata' were each located at a different place on the right part of the PCoA (Figure 4).

Similar results are presented in the STRUCTURE analysis (Figure 5). The plants are divided into two groups: the first comprises the 15 stock plants of I. aquifolium (1-15) and the certified I. aquifolium 'Agrifoglio Commune' plant (IA) with green color, and the second is I. aquifolium 'Hellas' (H) and I. aquifolium 'Argentea Marginata' (D) with red color.

The results of the dendrogram separated the individual plants into three different groups (Figure 7). Group 1 includes all the 15 stock plants (1-15) and the I. aquifolium 'Agrifoglio Commune' indicator plant (IA). Group 2 contains only I. aquifolium 'Argentea Marginata' (D), and group 3 consists of I. aquifolium 'Hellas' (H) plant (Figure 7). 

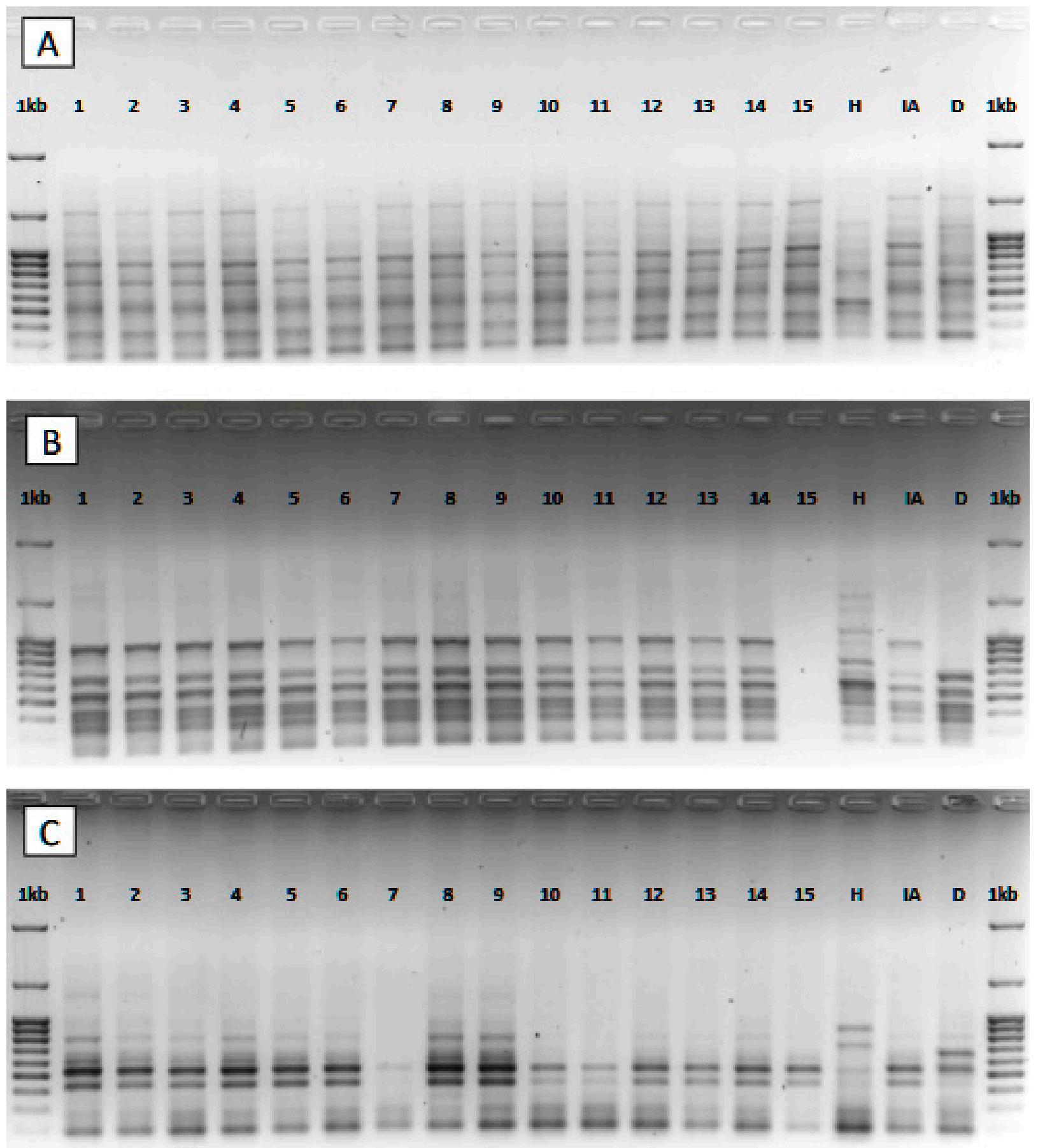

Figure 3. ISSR amplification profiles of the 15 stock plants (1-15), derived asexually from I. aquifolium plants grown at Polygyros (Greece), and the three I. aquifolium indicator plants, namely 'Agrifoglio Commune' (IA), 'Hellas' (H) and 'Argentea Marginata' (D), obtained with primers UBC-809 (A), UBC-815 (B) and UBC-834 (C). The size of the amplified bands was calculated using $1 \mathrm{~kb}$ DNA ladder (100-3000 bp). 


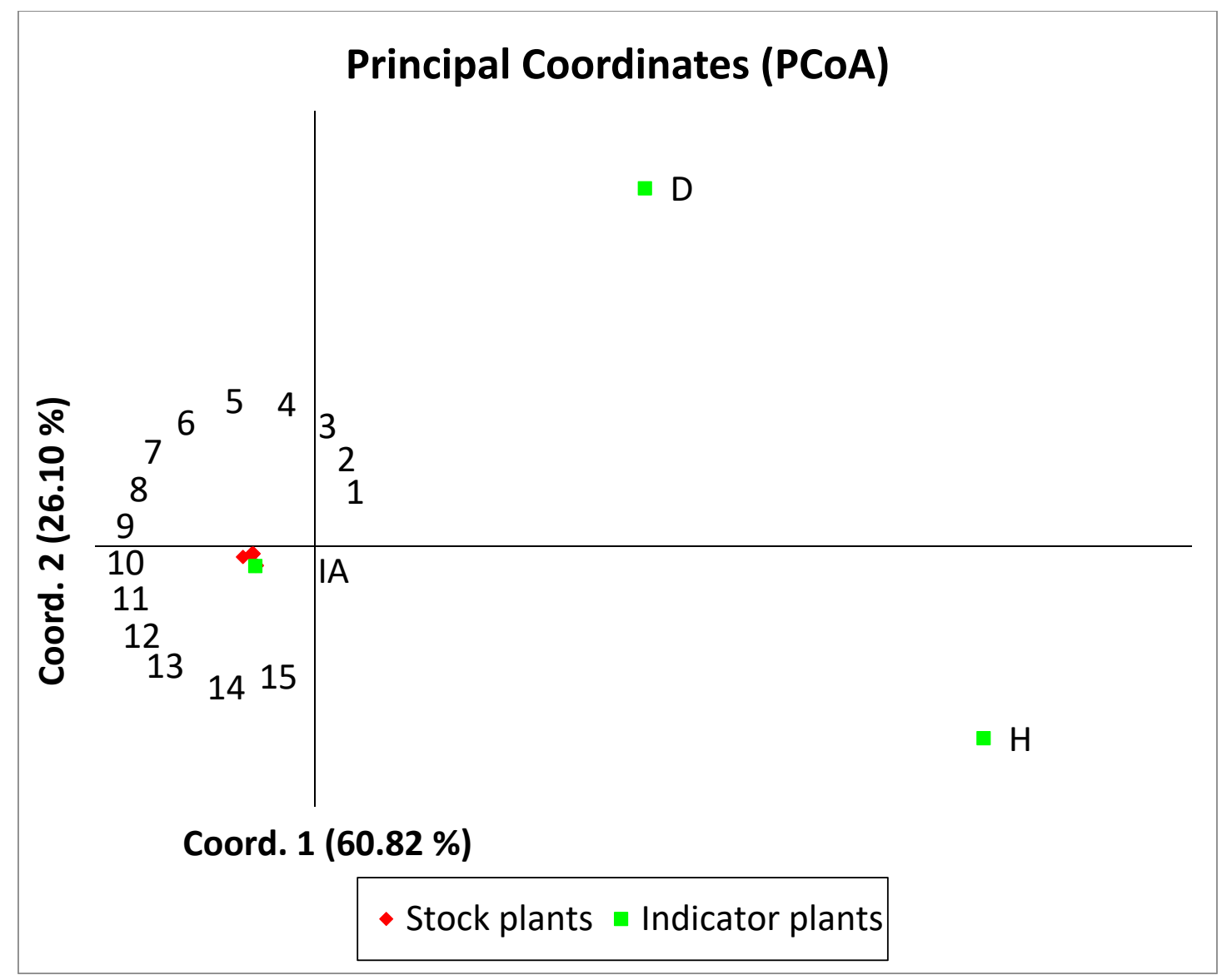

Figure 4. Principal coordinates analysis (PCoA) derived from bands amplified by eight ISSR primers of the 15 stock plants of I. aquifolium (red) and the 3 indicator plants (green) of I. aquifolium 'Agrifoglio Commune' (IA), I. aquifolium 'Hellas' (H) and I. aquifolium 'Argentea Marginata' (D).

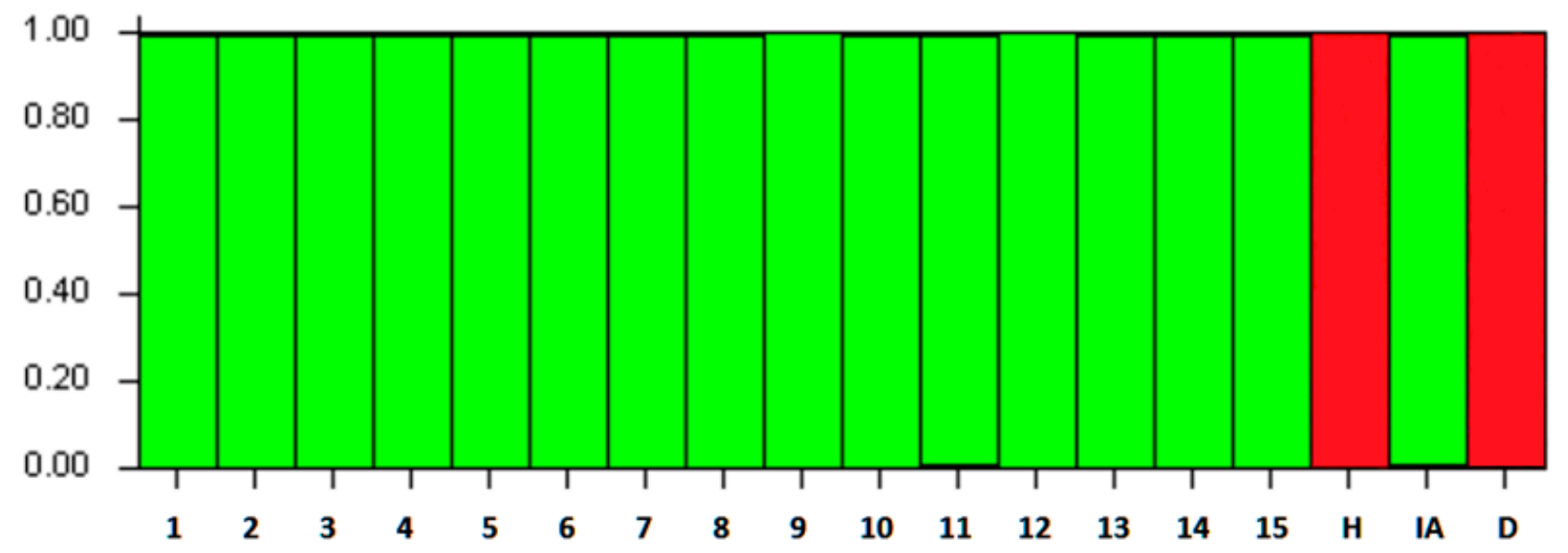

Figure 5. SRUCTURE analysis performed with data of eight ISSR primers for $K=2$ (higher value, Figure 6). Each column indicates the 15 I. aquifolium stock plants (1-15, green color) and the 3 indicator plants of I. aquifolium 'Hellas' (H, red color), I. aquifolium 'Agrifoglio Commune' (IA, green color) and I. aquifolium 'Argentea Marginata' (D, red color). 


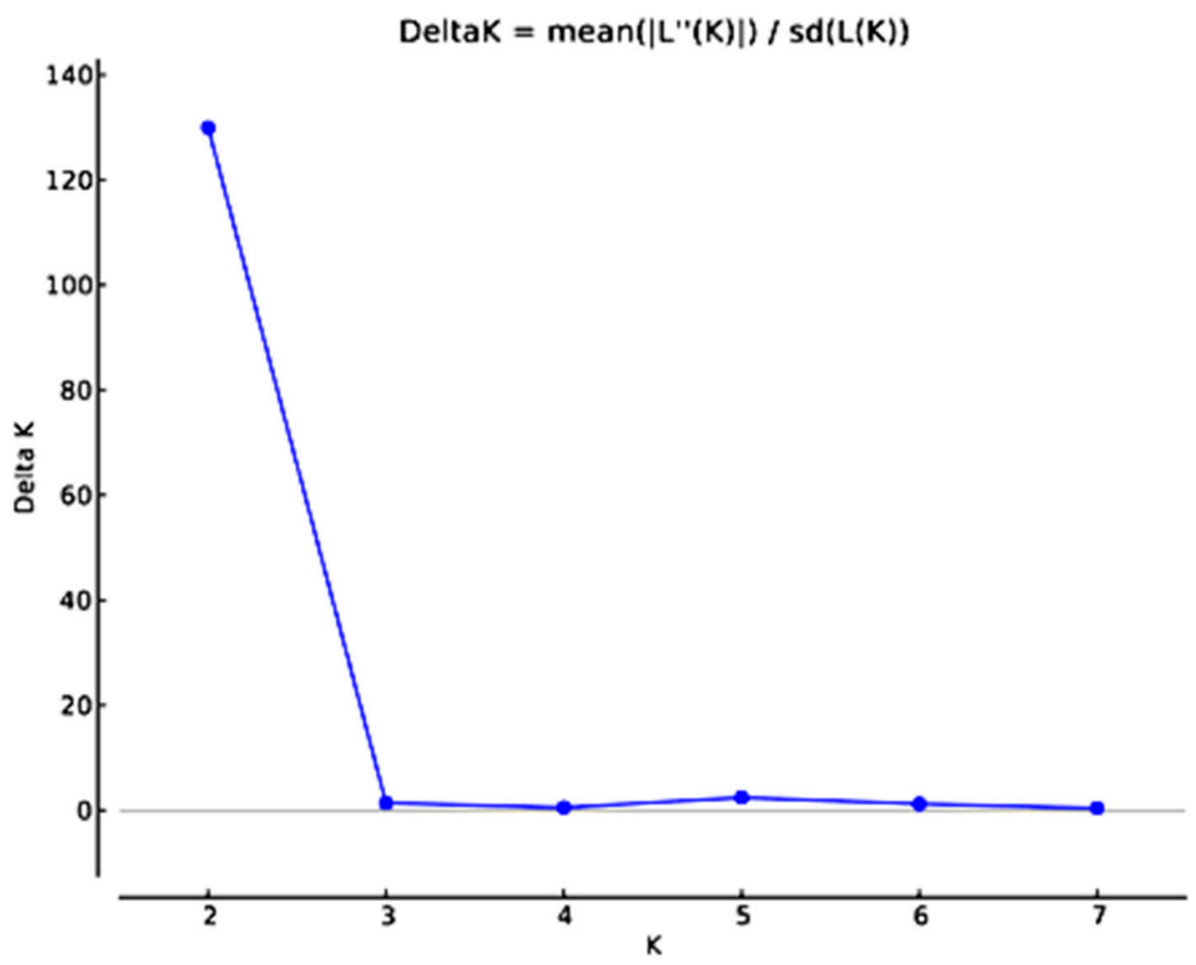

Figure 6. Estimation of the number of populations for $K$, from 1 to 8 , by calculating delta $K$ values.

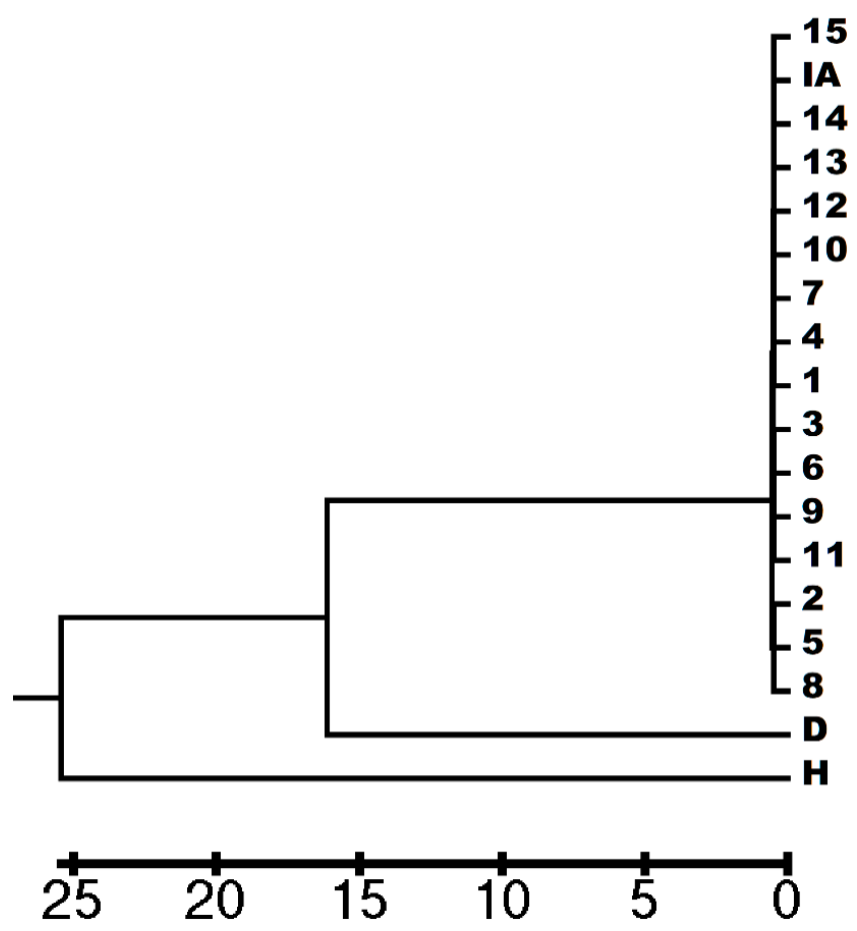

Figure 7. Dendrogram based on Nei standard genetic distance [25] using UPGMA method generated by eight ISSR primers among the 15 I. aquifolium stock plants (1-15) and the 3 indicator plants (I. aquifolium 'Agrifoglio Commune' (IA), I. aquifolium 'Argentea Marginata' (D) and I. aquifolium 'Hellas' (H)).

The 15 I. aquifolium stock plants are located at the same point of PCoA, simultaneously have the same color in STRUCTURE analysis and are in the same group of the dendrogram with the certified I. aquifolium 'Agrifoglio Commune' plant, indicating that these 15 stock plants and the certified plant share the same genetic material. In this case, it is obvious that 
the 15 stock plants were derived from authentic I. aquifolium 'Agrifoglio Commune' mother plants through asexual propagation. It is also clear that repeated asexual propagation of I. aquifolium 'Agrifoglio Commune', as might have happened in these plants, did not result in genetic differentiation. Similar genetic analysis with ISSR molecular markers was used in other species to find the genetic profile of asexually propagated plant genotypes, e.g., Pistacia lentiscus [45], or to detect genetic variation in micropropagated plants such as Platanus acerifolia [46], Prunus amygdalus [47], Phoenix dactylifera [48] and Vanilla planifolia [49]. Moreover, ISSRs have been successfully employed to assess the genetic stability of regenerants from artificial seeds of Viburnum dentatum [50], Rauvolfia tetraphylla [19], Rauvolfia serpentina [20] and Albizia lebbeck [51], and they have been used to study the genetic diversity of Pistacia lentiscus [52,53] and Mimosa caesalpiniaefolia [54].

\section{Conclusions}

The results of this study highlighted, beyond doubt, the important role of $0.2 \%$ NAA in the initiation and development of roots on terminal (preferably) shoot cuttings of Ilex aquifolium collected in autumn. Subterminal shoot cuttings collected in either season can also be used to further enrich the choices for suitable propagating material. For both types of cuttings and especially for those collected in autumn the period from the new plantlet establishment, after rooting, to the final product was less than a year. The genetic analysis through ISSR markers revealed that the stock plants used for collecting shoot cuttings for the propagation experiments belong to I. aquifolium 'Agrifoglio Commune', a species with desirable ornamental traits and sufficient adaptation potential in the Mediterranean and the Balkan Peninsula environments. Transfer of this underutilized plant material from the mountain area of Polygyros to the plain metropolitan area of Thessaloniki, without problems of adaptability, contributes to its ex situ conservation. Its value is further upgraded as this study guarantees the sustainable exploitation of this ornamental plant through continuous availability on the wholesale and/or retail market of uniform plant propagation material that retains its genetic fidelity. Propagators can rely on the simple and practical protocol developed herein for successful vegetative propagation of I. aquifolium 'Agrifoglio Commune' and rapid development of new plants with fruits in their final form available on market at the proper time of the year.

Supplementary Materials: The following are available online at https:/ /www.mdpi.com/article/10 $.3390 /$ su131810345/s1, Table S1: Eigenvalue, variance and scores of the three first factors retained from the PCoA of the eight ISSR markers performed on 18 I. aquifolium plants.

Author Contributions: Conceptualization, A.S., M.T., P.T., S.H., S.K., A.E. and I.I.; investigation, M.T., S.K., A.S., P.T., E.C., E.P., S.H., F.-T.Z. and I.N.-O.; resources, A.S., M.T., E.C., S.K., S.H. and I.I.; methodology, A.S., M.T., S.K., E.P., P.T., E.C., S.H., A.E., I.N.-O. and I.I.; visualization, S.K. and M.T.; data curation, M.T., E.C., E.P. and S.K.; writing—original draft preparation, A.S., M.T., S.K., P.T., E.P., S.H., I.N.-O. and F.-T.Z.; writing - review and editing, A.E., A.S., S.K. and I.I.; funding acquisition, A.E. and A.S.; project administration, A.S. and S.K. All authors have read and agreed to the published version of the manuscript.

Funding: Financial support for this study was provided by the National Strategic Reference Framework (NSRF) 2007-2013, Industrial Research and Technology Development Program (PAVET) 2013 (grant No. 1015-BET-2013), with the co-financing of Greece and the European Union.

Institutional Review Board Statement: Not applicable.

Informed Consent Statement: Not applicable.

Data Availability Statement: Not applicable.

Acknowledgments: Authors' collaboration from the two institutions was encouraged by the 'Academic Cooperation Framework Agreement between the University of Forestry-Sofia, Bulgaria and the Aristotle University of Thessaloniki, Greece', November 2019. Thanks to the anonymous reviewers for their helpful comments and suggestions. 
Conflicts of Interest: The authors declare no conflict of interest.

\section{References}

1. Guerrero-Hue, N.; Caudullo, G.; de Rigo, D. Ilex aquifolium in Europe: Distribution, habitat, usage and threats. In European Atlas of Forest Tree Species; San-Miguel-Ayanz, J., de Rigo, D., Caudullo, G., Houston Durrant, T., Mauri, A., Eds.; Publication Office EU: Luxembourg, 2016; p. 102.

2. Niemiera, A.X. Evergreen Hollies (Ilex spp.); Virginia Cooperative Extension; Virginia Tech and Virginia State University: Blacksburg, VA, USA, 2018; pp. 1482-1487.

3. Peterken, G.F.; Lloyd, P.S. Ilex aquifolium L. J. Ecology 1967, 55, 841-858. [CrossRef]

4. Hartmann, H.T.; Kester, D.E.; Davies, F.T., Jr.; Geneve, R.L. Hartmann and Kester's Plant Propagation: Principles and Practices, 8th ed.; Prentice Hall: Upper Saddle River, NJ, USA, 2011; p. 915.

5. Dirr, M.A.; Heuser, C.W., Jr. The Reference Manual of Woody Plant Propagation: From Seed to Tissue Culture; Varsity Press: Athens, GA, USA, 1987; p. 239.

6. French, C.L.; Liu, W.C. Seasonal variation in the effects of $\mathrm{CO}_{2}$, mist and supplementary lightening from high pressure sodium lamps on rooting of English holly cuttings. HortScience 1984, 19, 519-521.

7. Rifaki, N.; Economou, A.; Scaltsoyiannes, A. Factors affecting the rooting of Ilex aquifolium L. cuttings. Prop. Ornam. Plants 2001, 1, 31-35.

8. Tsaktsira, M.; Alevropoulos, A.; Tsoulpha, P.; Scaltsoyiannes, V.; Scaltsoyiannes, A.; Iliev, I. Inter- and intra-genetic variation on rooting ability of Ilex aquifolium L. varieties and cultivars. Prop. Ornam. Plants 2018, 18, 131-138.

9. Blythe, E.K.; Sibley, J.L.; Tilt, K.M.; Ruter, J.M. Auxin application to stem cuttings of selected woody landscape plants by incorporation into a stabilized organic rooting substrate. J. Environ. Hort. 2004, 22, 63-70. [CrossRef]

10. Blythe, E.; Sibley, J. Sodium cellulose glycolate as a thickening agent for liquid auxin formulations can enhance rooting of stem cuttings. J. Environ. Hort. 2007, 25, 126-130. [CrossRef]

11. Lambert, C.R.; Blazich, F.A.; LeBude, A.V. Propagation of Ilex vomitoria 'Dare County' by stem cuttings. J. Environ. Hort. 2012, 30, 55-57. [CrossRef]

12. Blythe, E.; Sibley, J. Winter stem cutting propagation of 'Dwarf Burford' holly without use of a conventional auxin treatment. HortTechnology 2009, 19, 130-132. [CrossRef]

13. Blythe, E.K.; Sibley, J.L. Winter stem cutting propagation of Heller's Japanese holly with and without the use of a conventional auxin treatment. HortTechnology 2012, 22, 771-773. [CrossRef]

14. Maynard, B.K. Evaluating the role of $\mathrm{pH}$ in the rooting of cuttings. Comb. Proc. Int. Plant Prop. Soc. 2000, 50, $268-273$.

15. Jabbarzadeh, Z.; Khosh-Khui, M.; Salehi, H.; Saberivand, A. Inter simple sequence repeat (ISSR) markers as reproducible and specific tools for genetic diversity analysis of rose species. Afr. J. Biotechol. 2010, 9, 6091-6095.

16. Ng, W.L.; Tan, S.G. Inter-simple sequence repeat (ISSR) markers: Are we doing it right. ASM Sci. J. 2015, 9, 30-39.

17. Pakseresht, F.; Talebi, R.; Karami, E. Comparative assessment of ISSR, DAMD and SCoT markers for evaluation of genetic diversity and conservation of landrace chickpea (Cicer arietinum L.) genotypes collected from north-west of Iran. Physiol. Mol. Biol. Plants 2013, 19, 563-574. [CrossRef]

18. Cuesta, C.; Ordas, R.J.; Rodriguez, A.; Fernandez, B. PCR-based molecular markers for assessment of somaclonal variation in Pinus picea clones micro-propagated in vitro. Biol. Plant. 2010, 54, 435-442. [CrossRef]

19. Alatar, A.; Faisal, M. Encapsulation of Rauvolfia tetraphylla microshoots as artificial seeds and evaluation of genetic fidelity using RADP and ISSR markers. J. Medic. Plants Res. 2012, 6, 1367-1374.

20. Faisal, M.; Alatar, A.A.; Ahmad, N.; Anis, M.; Hegazy, A.K. Assessment of genetic fidelity in Rauvolfia serpentina plantlets grown from synthetic (encapsulated) seeds following in vitro storage at $4{ }^{\circ} \mathrm{C}$. Molecules 2012, 17, 5050-5061. [CrossRef] [PubMed]

21. Mehrotra, S.; Khwaja, O.; Kukreja, A.K.; Rahman, L. ISSR and RAPD based evaluation of genetic stability of encapsulated micro shoots of Glycyrrhiza glabra following 6 months of storage. Mol. Biotechnol. 2012, 52, 262-268. [CrossRef] [PubMed]

22. Hatzilazarou, S.; Kostas, S.; Nendou, T.; Economou, A. Conservation, regeneration and genetic stability of regenerants from alginate-encapsulated shoot explants of Gardenia jasminoides Ellis. Polymers 2021, 13, 1666. [CrossRef]

23. Graf, W. Key for the main assortment of Ilex aquifolium cultivars in Central Europe based on leaf morphology. Acta Hortic. 2008, 885, 123-130. [CrossRef]

24. Klockars, A.J.; Sax, G. Post hoc comparisons: The Scheffe test. In Multiple Comparisons; Klockars, A.J., Sax, G., Eds.; Sage Publications: Beverly Hills, CA, USA, 1986; Volume 61, pp. 58-61.

25. Nei, M. Genetic distance between populations. Amer. Naturalist 1972, 106, 283-292. [CrossRef]

26. Peakall, R.; Smouse, P.E. GENALEX 6: Genetic analysis in Excel. Population genetic software for teaching and research. Mol. Ecol. Notes 2006, 6, 288-295. [CrossRef]

27. Pritchard, J.K.; Wen, X.; Falush, D. Documentation for Structure Software: Version 2.3; University of Chicago: Chicago, IL, USA, 2010; p. 38.

28. Baldoni, L.; Tosti, N.; Ricciolini, C.; Belaj, A.; Arcioni, S.; Pannelli, G.; Germana, M.A.; Mulas, M.; Porceddu, A. Genetic structure of wild and cultivated olives in the Central Mediterranean basin. Ann. Bot. 2006, 98, 935-942. [CrossRef] 
29. Ganopoulos, I.V.; Kazantzis, K.; Chatzicharisis, I.; Karayiannis, I.; Tsaftaris, A.S. Genetic diversity, structure and fruit trait associations in Greek sweet cherry cultivars using microsatellite based (SSR/ISSR) and morpho-physiological markers. Euphytica 2011, 181, 237-251. [CrossRef]

30. Evanno, G.; Regnaut, S.; Goudet, J. Detecting the number of clusters of individuals using the software STRUCTURE: A simulation study. Mol. Ecol. 2005, 14, 2611-2620. [CrossRef]

31. Earl, D.A.; vonHoldt, B.M. STRUCTURE HARVESTER: A website and program for visualizing STRUCTURE output and implementing the Evanno method. Conserv. Genet. Resour. 2012, 4, 359-361. [CrossRef]

32. Tamura, K.; Dudley, J.; Nei, M.; Kumar, S. MEGA 4: Molecular evolutionary genetics analysis (MEGA) software version 4.0. Mol. Biol. Evol. 2007, 24, 1596-1599. [CrossRef]

33. Vlad, M.; Vlad, I.; Vlad, I.A.; Cheregi, G. Research on the improvement of propagation technology in Ilex aquifolium. Ann. Univ. Oradea 2015, 25, 141-144.

34. Mbangcolo, M.M.; Reinten, E.Y.; Agenbag, G.A. Effect of species, cutting position and exogenous rooting substances on rooting of honeybush (Cyclopia spp.) cuttings. S. Afr. J. Plant Soil 2013, 30, 53-55. [CrossRef]

35. Malan, D.G. Propagation of Proteaceae. Acta Hortic. 1992, 316, 27-34. [CrossRef]

36. Brock, J.A.; Griffin, J.J. Rooting response of stem cuttings of Shantung maple (Acer truncatum) to time of year, cutting position, and auxin concentration, formulation, and solvent. J. Environ. Hort. 2014, 32, 163-166. [CrossRef]

37. Tilahun, A.; Manahlie, B.; Abebe, G.; Negash, G. Effect of cutting position and indole butyric acid (auxin) concentration on rooting response of Araucaria heterophylla. Afr. J. Biotechnol. 2019, 18, 86-91.

38. Stephen, O.U.; Chikordi, A.I. Age of stem cuttings and its effect on the growth of Manihot spp. World J. Agric. Sci. 2015, 3, 1-3.

39. Mashudi, M.; Adinugraha, H.A. The growth success of Alstonia scholaris (L.) R. Br. shoot cuttings from several shoots position and the cut type of cuttings. J. Penel. Kehut. Wallacea 2015, 4, 63-69. [CrossRef]

40. Solikin, S. Effect of nodes position on the growth and yield of stem cutting of sambiloto (Andrographis paniculata). Nusantara Biosci. 2018, 10, 226-231. [CrossRef]

41. Beemnet, M.K.; Aster, K.; Solomon, A.M. Effect of node number, part used and season of propagation on nursery establishment of lemon verbena (Aloysia triphylla L.). In Improving Quality Production of Horticultural Crops for Sustainable Development Proceedings, Jimma, Ethiopia, 4-5 February 2011; Jimma University College of Agriculture and Veterinary Medicine: Jimma, Ethiopia, 2012; pp. 121-133.

42. Beemnet, M.K.; Solomon, A.M. Effect of cutting position and rooting hormone on propagation ability of stevia (Stevia rebaudiana Bertoni). Afr. J. Plant. Sci. Biotechnol. 2012, 6, 5-8.

43. Zewdinesh, D.Z.; Beemnet, M.K.; Bazaznew, D. Effect of cutting size and position on propagation ability of lavender (Lavandula angustifolia L.). In Proceedings of the 4th Biennial Conference of Ethiopian Horticultural Science Society, Ambo, Ethiopia, 12-13 April 2013; pp. 129-137.

44. Zewdinesh, D.Z.; Beemnet, M.K. Effect of cutting size and position on propagation ability of sage (Salvia officinalis L.). Int. J. Adv. Biol. Biomed. Res. 2016, 4, 68-76.

45. Kostas, S.; Hatzilazarou, S.; Pipinis, E.; Vasileiadis, A.; Magklaras, P.; Smyrnioudis, I.; Vasilakis, T.; Chazakis, M.; Anastasiadi, V.; Ziogou, F.-T.; et al. Propagation of Pistacia lentiscus var. Chia genotypes and determination of their ornamental traits combined with a genetic analysis using ISSR markers. Agronomy 2021, 11, 205. [CrossRef]

46. Huang, W.J.; Ning, G.G.; Liu, G.F.; Bao, M.Z. Determination of genetic stability of long-term micropropagated plantlets of Platanus acerifolia using ISSR markers. Biol. Plant 2009, 53, 159-163. [CrossRef]

47. Martins, M.; Sarmento, D.; Oliveira, M.M. Genetic stability of micropropagated almond plantlets, as assessed by RAPD and ISSR markers. Plant Cell Rep. 2004, 23, 492-496. [CrossRef] [PubMed]

48. Kumar, N.; Modi, A.R.; Singh, A.S.; Gajera, B.B.; Patel, A.R.; Patel, M.P.; Subhash, N. Assessment of genetic fidelity of micropropagated date palm (Phoenix dactylifera L.) plants by RAPD and ISSR markers assay. Physiol. Mol. Biol. Plants 2010, 16, 207-213. [CrossRef] [PubMed]

49. Solano, M.C.P.; Ruiz, J.S.; Arnao, M.T.G.; Castro, O.C.; Tovar, M.E.G.; Bello, J.J.B. Evaluation of in vitro shoot multiplication and ISSR marker based assessment of somaclonal variants at different subcultures of vanilla (Vanilla planifolia Jacks). Physiol. Mol. Biol. Plants 2019, 25, 561-567. [CrossRef]

50. Hatzilazarou, S.; Kostas, S.; Joachim, M.; Economou, A. Regeneration of Viburnum dentatum L. from alginate-encapsulated shoot explants after short-term cold storage and assessment of genetic stability using ISSR analysis. Agronomy 2020, 10, 1660. [CrossRef]

51. Saeed, T.; Shahzad, A.; Sharma, S. Studies on single and double layered biocompatible encapsulation of somatic embryos in Albizia lebbeck and genetic homogeneity appraisal among synseed derived lines through ISSR markers. Plant Cell Tiss. Org. Cult. 2020, 140, 431-445. [CrossRef]

52. Zografou, P.; Linos, A.; Hagidimitriou, M. Genetic diversity among different genotypes of Pistacia lentiscus var. Chia (mastic tree). Options Mediterr. 2010, 94, 159-163.

53. Abuduli, A.; Aydin, Y.; Sakiroglu, M.; Onay, A.; Ercisli, S.; Uncuoglu, A.A. Molecular evaluation of genetic diversity in wild-type mastic tree (Pistacia lentiscus L.). Biochem. Genet. 2016, 54, 619-635. [CrossRef] [PubMed]

54. Araujo, F.S.; Pacheco, M.V.; Vieira, F.A.; Ferrari, C.S.; Felix, F.C.; Chagas, K.P.T. ISSR molecular markers for the study of the genetic diversity of Mimosa caesalpiniaefolia Benth. Idesia 2016, 34, 47-52. [CrossRef] 